\title{
Vitamin A metabolic aspects and alcoholic liver disease
}

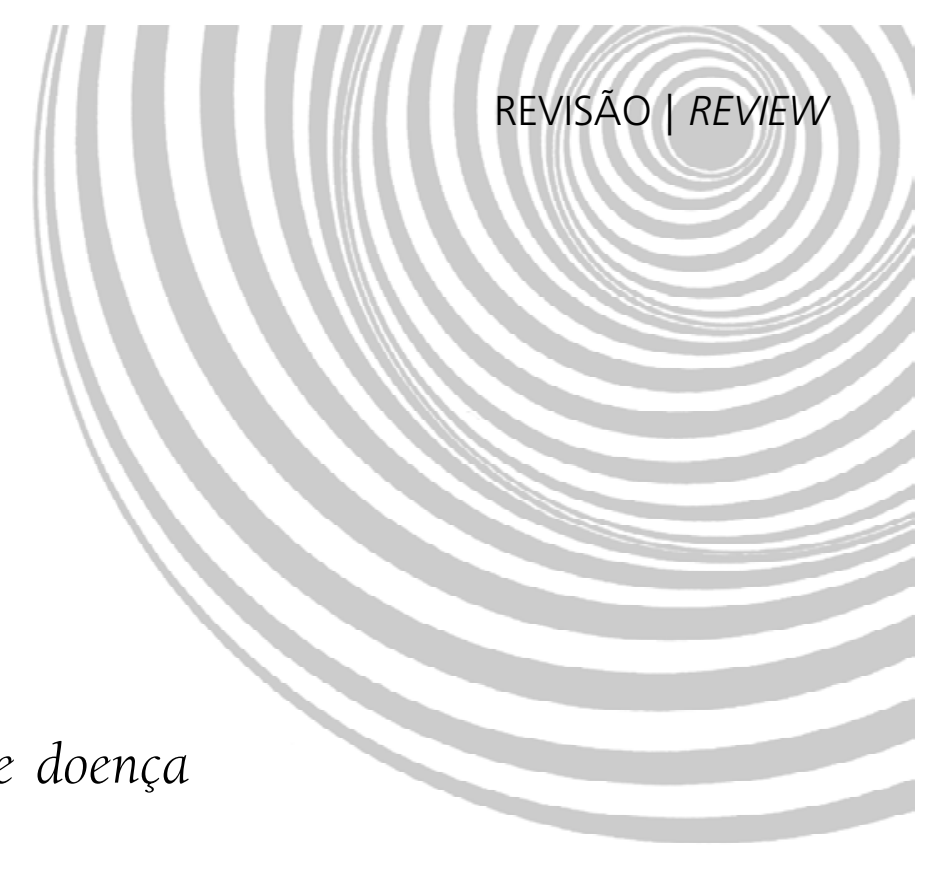

\section{Aspectos metabólicos da vitamina A e doença hepática alcoólica}

\author{
Tatiana Pereira de PAULA ${ }^{1}$ \\ Wilza Arantes Ferreira PERES 2 \\ Rejane Andréa RAMALHO ${ }^{3}$ \\ Henrique Sérgio Moraes COELHO${ }^{4}$
}

A B S T R A C T

The liver is a strategic organ in the metabolism of macro and micronutrients; when its functioning is compromised, it may cause some change in the nutritional status of vitamin A. The purpose of this article is to review scientific evidence in literature on the liver metabolism of vitamin $A$, the role of ethanol and retinol interactions on hepatic morphology, besides the alterations in the metabolism of this vitamin in alcoholic liver disease. Data were collected from Medline database. The liver is the main organ responsible for the storage, metabolism and distribution of vitamin A to peripheral tissues. This organ uses retinol for its normal functioning such as cell proliferation and differentiation. This way, vitamin A deficiency seems to alter liver morphology. Patients with alcoholic liver disease have been found to have low hepatic levels of retinol in all stages of their disease. In alcoholic liver disease, vitamin A deficiency may result from decreased ingestion or absorption, reduction in retinoic acid synthesis or increased degradation. Long-term alcohol intake results in reduced levels of retinoic acid, which may promote the development of liver tumor. So, in chronic alcoholic subjects, vitamin A status needs to be closely monitored to avoid its deficiency and clinical effects, however its supplementation must be done with caution since the usual dose may be toxic for those who consume ethanol.

Indexing terms: vitamin A deficiency; ethanol; liver; alcoholic liver disease; tretinoin; vitamin A.

\footnotetext{
1 Nutricionista, Hospital Universitário Clementino Fraga Filho, Universidade Federal do Rio de Janeiro. Av. Prof. Rodolpho P. Rocco, s/n, Ilha do Fundão, Rio de Janeiro, RJ, Brasil. Correspondência para/Correspondence to: E-mail: $<$ tatidepaula@yahoo.com.br>.

2 Departamento de Nutrição e Dietética, Instituto de Nutrição Josué de Castro, Universidade Federal do Rio de Janeiro. Rio de Janeiro, RJ, Brasil.

3 Departamento de Nutrição Social e Aplicada, Instituto de Nutrição Josué de Castro, Universidade Federal do Rio de Janeiro. Rio de Janeiro, RJ, Brasil

${ }^{4}$ Departamento de Clínica Médica, Setor Hepatologia, Hospital Universitário Clementino Fraga Filho, Universidade Federal do Rio de Janeiro. Rio de Janeiro, RJ, Brasil.
} 


\section{RES U M O}

O fígado é um órgão estratégico no metabolismo de macro e de micronutrientes e, portanto, é de esperar que o comprometimento de sua função seja acompanhado de alterações no estado nutricional de vitamina $A$. $O$ objetivo deste artigo é revisar na literatura evidências científicas sobre o metabolismo hepático da vitamina $A$, o efeito das interações entre a vitamina A e o etanol sobre a morfologia hepática, além das alterações do metabolismo dessa vitamina na doença hepática alcoólica. Os dados foram selecionados na base de dados Medline no período de 1979 a 2005. O fígado é o principal órgão responsável pelo armazenamento, metabolismo e distribuição da vitamina A para os tecidos periféricos. Esse órgão utiliza retinol para seu funcionamento normal como proliferação e diferenciação celular. Dessa forma, a deficiência dessa vitamina parece alterar a morfologia hepática. Baixos níveis de retinol hepático têm sido encontrados em todos os estágios da doença hepática alcoólica. A deficiência de vitamina A na doença hepática alcoólica pode resultar da diminuição da sua ingestão ou absorção, na redução da síntese de ácido retinóico ou na diminuição da sua degradação. A ingestão crônica de álcool resulta em níveis reduzidos de ácido retinóico, o que favorece a formação de tumor hepático. Logo, em etilistas crônicos o estado nutricional de vitamina A deve ser monitorado, para evitar sua deficiência e seus sintomas clínicos, embora a suplementação deva ser feita com cautela, pois doses comumente usadas podem ser tóxicas para aqueles que consomem etanol.

Termos de indexação: deficiência de vitamina A; etanol; fígado; doença hepática alcoólica; tretinoína; vitamina $A$.

\section{INTRODUCTION}

Alcoholic liver disease is one of the most common causes of liver cirrhosis in Occident, and it is among the ten most common causes of death by liver disease in the world'. Alcoholic liver disease has a wide clinical spectrum; it may progress to cirrhosis and to end-stage liver disease ${ }^{2}$.

Vitamin A participates in several biological mechanisms, as epithelial differentiation, gene expression, reproduction, normal vision and integrity of the immune system ${ }^{3}$. The liver plays a central role in the uptake, storage and is also the oxidation site of vitamin A catabolism and responsible for the regulated release of this vitamin to other tissues ${ }^{4}$.

By this way, direct effects of ethanol on liver may interfere on vitamin A metabolism and hepatic levels. Patients with alcoholic liver disease have been found to have low hepatic levels of retinol at all the stages of their disease ${ }^{5}$. Furthermore, the interaction between vitamin A and ethanol may result in structural hepatic alterations.

The current work intents to gather information about the liver metabolism of vitamin $A$, the role of the interaction between retinol and ethanol in the liver morphology, besides the alteration of the metabolism of this vitamin in the liver disease. This approach aims to increase awareness of this nutritional condition in different stages of the liver disease.

It's a review work, based in the available articles of periodicals enlisted by Medline. To make the search of the bibliographic references, it was considered the ones published within 1979 to 2005 , which contained the key-words: liver, vitamin $A$ metabolism, alcoholic liver disease, vitamin $A$ deficiency, retinoic acid and ethanol. Considering the amount of scientific evidence available about the proposed subject and aiming the better application, the information obtained was assembled, organized and critically evaluated. The selection of the works was guided by experimental studies and studies with human beings, and the inconclusive studies were excluded of this review.

\section{Vitamin A metabolism in the liver}

The liver consists of several cell types, of which two (hepatocytes or parenchymal cells and stellate cells) are directly involved in the metabolism of vitamin $\mathrm{A}^{6}$.

Around $50 \%-90 \%$ of retinol ingested is absorbed via the lymphatics and carried by chylomicrons and chylomicron remnants, as retinyl 
esters, to the liver and taken up by the parenchymal cells ${ }^{7}$. In these cells, the retinyl esters are hydrolyzed and the free retinol is bound to cellular retinol binding protein I (CRPB1) and then transferred to the stellate cells, also called lipocytes, fat-storing cells or Ito cells ${ }^{8}$.

The stellate cells, which in normal conditions contain about $90 \%$ of hepatic retinol, are responsible for uptake, storage and release of the retinol. In these cells, retinol bound to CRPB1 is esterified by the lecithin: retinol acyltransferase and retinyl esters are stored in lipid droplets of these cells. When retinol is present at high levels and the CRBP1 becomes saturated, acyl CoA: retinol acyltransferase may esterify the excess ${ }^{6}$. Thus, the hepatic retinol esterification depends on the amount of retinol present and whether retinol is bound to cellular retinol binding protein ${ }^{8,9}$. About $98 \%$ percent of the stellate cell vitamin $A$ is in the form of retinyl esters ${ }^{6}$. The mobilization of retinol from stellate cells, occurs after the hydrolysis of retinyl esters and retinol is bound to retinol binding protein, and the holo-retinol binding protein complex formed is released. However, both parenchymal cells and stellate cells can secrete this complex to the bloodstream, but the release from stellate cells seems to be the predominant pathway ${ }^{6,10}$. In the blood, the holo-retinol binding protein complex is associated with the transthyretin, a protein also synthesized in the liver. Retinol then is removed from bloodstream and used by the target cells through specific receptors for active retinoids or its metabolites, especially retinoic acid, existing in the surface of the cells and nucleus ${ }^{11,12}$.

Retinol, the major circulating form of vitamin $\mathrm{A}$, is not biologically active and serves as a metabolic precursor of active retinoids. These are generated intracellularly by two oxidative enzymatic reactions in which retinol is first converted into retinaldehyde and then to retinoic acids.

\section{Vitamin A deficiency and liver disease}

The decrease in serum levels of retinol is frequently found in patients with liver cirrhosis and it can be explained by the reduced hepatic vitamin storage, synthesis and/or diminished release of binding proteins by the liver ${ }^{13}$. Another factor could be influenced by the deficient enzymatic conversion of $\beta$-carotene into retinol, which also occurs in liver ${ }^{14}$. Other factors such as chronic inflammation and infection, which are part of clinical manifestations of liver cirrhosis, are also responsible for the reduction of the serum levels of retinol. This can be attributed to the reduction in the synthesis and release of retinol binding protein, during acute phase response $\mathrm{e}^{15,16}$. In this case, decrease in serum levels can be transient and not related to the lower hepatic vitamin $A$ storage $^{16}$.

The decrease in serum levels of vitamin A can be aggravated by the degree of liver disease. Rocchi et al. ${ }^{17}$, in a study developed with cirrhotic patients, found a narrow correlation between the serum reduction of retinol and the severity of the disease, according to the classification of Child \& Pugh $^{18}$, that it is based on clinical and biochemical data and may be considered as a survival predictor for these patients.

The inadequate consumption of vitamin A leads to the depletion of its organic reserves. In patients with cirrhosis, the inadequate intake of this vitamin, mainly the vitamin A from animal sources, which is highly available, can exacerbate an expected reduction in the serum levels of vitamin $\mathrm{A}$. In addition, the reduction in protein ingestion, by unfounded patient's belief or inadequate recommendations in clinical practice, as prophylaxis for the hepatic encephalopathy contributes for the reduction of vitamin A from animal sources daily ingestion and the decreasing of bioconversion of provitamin A carotenoids. In agreement, the administration of low protein diets in rats showed to reduce the activity of $\beta$-carotene 15-15'monooxygenase, besides limiting the retinol binding protein synthesis ${ }^{19}$.

Moreover, the liver disease can course with intestinal alteration ${ }^{20}$ that can compromise the bioavailability and the bioconversion of carotenoids in vitamin $\mathrm{A}$. 


\section{Ethanol and retinol interactions associated with hepatic structural alterations}

It is suggested that the liver also works as a vitamin A storage site and it can use retinol for a normal functioning like cell proliferation and differentiation ${ }^{21,22}$. This way, vitamin A deficiency seems to alter the hepatic morphology and may be associated with hepatic structural alterations .

Leo et al. ${ }^{23}$ evaluated the serum and hepatic levels of vitamin $A$ in 41 patients with liver disease from several etiologies and compared these results to some alterations in hepatic morphology. These authors observed the relationship between hepatic vitamin A deficiency and the appearance of multivesicular lysosomes. These organelles seem to be filled with numerous particles like lipoprotein that suggest an abnormality in lipoprotein secretion. Searching for differentiating the ethanol toxic action from vitamin A action in lesion etiology, these researchers performed an experimental protocol in rats by administrating vitamin A-replete or deplete diets, with or without ethanol. As result, these authors suggested that ethanol can potentiate the effect of vitamin A deficiency, which was indicated by high frequency of multivesicular lysosomes in animals that received ethanol and deficient diet in vitamin A. However, these lesions were observed in animals fed with vitamin A deficient diet without ethanol as well as in patients with vitamin A deficiency and without alcoholic liver disease, while normal vitamin A diet, with or without ethanol, did not result in the appearance of multivesicular lysosomes in rats. Thus, multivesicular lysosomes appearance may be associated with low hepatic vitamin A levels, although this type of lesion is not considered a histopathological sign of vitamin A deficiency.

In patients with alcoholic liver disease, low levels of hepatic vitamin A has been associated with the presence of Mallory bodies which seems a pathological keratinization of the hepatocytes ${ }^{24-26}$. However, Mallory bodies were also observed in patients with alcoholic liver disease and normal concentration of vitamin A while patients with low vitamin A concentration and liver disease induced by drugs did not have any Mallory bodies $^{27}$. Leo et al. ${ }^{5,23}$ did not verify relationship between the decrease of hepatic vitamin A concentration and the appearance of Mallory bodies in livers biopsied from alcoholic subjects and in rats fed with ethanol. Although this relationship has not been observed, one cannot exclude that vitamin A deficiency may potentiate the role of ethanol in the appearance of Mallory bodies $^{27}$.

Ethanol can activate stellate cells by several mechanisms, associated with ethanol metabolism, including direct fibrogenic action of acethaldehyde (a highly toxic metabolite), induction of oxidative stress, and increased lactate ${ }^{28-32}$. Stellate cells activation into myofibroblasts-like cells, responsible for the synthesis of collagen, results in hepatic fibrosis and is associated with a decrease in vitamin A storage in these cells ${ }^{33}$. This reduction may have a casual role in this cellular transformation, since in a culture of stellate cells was demonstrated that retinol and especially the retinoic acid reduced the proliferation of these cells, the collagen synthesis and the transformation into myofibroblasts-like cells. Thus, vitamin A deficiency may lead to hepatic fibrosis ${ }^{34}$. In vitro, rats' stellate cell transformation into fibroblasts was inhibited by the cell exposition to retinol ${ }^{33}$.

\section{Vitamin A and alcoholic liver disease}

Alcoholic liver disease normally courses with alteration in nutritional status of vitamin $\mathrm{A}^{35,36}$. Reduced levels of retinol have been found in serum of chronic alcoholic subjects, with or without hepatic disease, and in liver biopsies from alcoholic subjects ${ }^{5}$.

Calamita et al. ${ }^{37}$, in a study with patients with alcoholic cirrhosis, observed that all of them presented decreased serum retinol concentrations.

Several factors may contribute for this alteration, such as: decrease in micro and macronutrient intake, decreased retinol absorption, 
enhanced degradation in the liver and an increased mobilization of retinol from the liver to other organs ${ }^{27,35}$. Moreover, oxidative stress, induced by chronic ethanol ingestion, may increase demands of several antioxidants including vitamin $\mathrm{A}^{38}$.

Like ethanol, retinol is an alcohol and, in vitro, both can be converted to corresponding aldehydes in reactions catalyzed by several isoenzymes of cytosolic alcohol dehydrogenase. It is expected that in vitro and, possibly, in vivo these two alcohols may compete for the same or similar enzymatic pathways. By this way, ethanol consumption affects retinol metabolism and function ${ }^{27}$.

Ethanol, both in acute and chronic intakes, induces an important depletion in hepatic vitamin $A$ and alters the distribution of this vitamin to others tissues 23,39 . This reduction may be caused by decreased of hepatic uptake ${ }^{40}$ or by the increased metabolism of this vitamin ${ }^{39}$. It has been observed that alcoholic liver disease is associated with the reduction of the concentration of vitamin $A$ in the liver, even when the hepatic injury is mild, as in steatosis, and when serum concentration of this vitamin, retinol binding protein and transthyretin are normal ${ }^{27,28,36}$. This way, the serum levels of vitamin A may not reflect the vitamin A status in chronic alcoholic subjects with or without hepatic disease ${ }^{14}$, as in healthy subjects, since serum retinol level is kept constant until vitamin A liver reserve is nearly exhausted.

Ukleja et al. ${ }^{41}$ in a prospective study with liver transplantation candidates with several etiologies, found that patients with alcohol-related cirrhosis had the lowest median for total hepatic vitamin $A$, as well as the lowest median for serum retinol concentration, when compared to patients with other etiologies.

Low levels of plasma vitamin A may even be attributed to decreased synthesis of retinol binding protein by the liver. Moreover, alcoholic cirrhosis is normally associated with zinc deficiency, which may contribute to the decrease of retinol binding protein synthesis, and consequently, impairs vitamin A mobilization ${ }^{27}$. Protein-calorie malnutrition usually present in these patients ${ }^{42}$, with prevalence between $34 \%$ to $87 \%$, reaching about $100 \%$ in hospitalized patients ${ }^{43}$, also contributes to reduced transport of vitamin $A$ since one of the main causes is decreased dietary intake of both micro and macronutrients, mainly reduced protein intake, which also limits RBP synthesis ${ }^{44}$.

Vitamin A status may be worse in late stages of liver disease. Bell et al. ${ }^{45}$, found relation between reduced levels of hepatic vitamin $A$ and decreased activity of prothrombin in patients with alcoholic liver disease and suggested that the hepatic vitamin A level is related to the decrease of the hepatic function

Vitamin A deficiency may result in hipogonadism as consequence of testicular atrophy and decreased spermatogenesis, and night blindness ${ }^{46}$ due to reduced rate of regeneration of visual pigment rhodopsin (opsin conjugated to retinal), compromising visual adaptation to dim light ${ }^{11}$.

In a study using two animal models, Sato \& Lieber ${ }^{47}$ observed in baboons the decreasing in vitamin A hepatic concentration equivalent to $59 \%, 67 \%$ and $95 \%$ after a mean of 4,12 and 60 months of ethanol feeding, respectively. In the first two groups was observed the appearance of hepatic steatosis while the last one developed fibrosis or cirrhosis. In rats, was demonstrated the decrease of vitamin A hepatic concentration after three weeks of ethanol administration with progressive reduction during the nine weeks of study. In relation to plasma retinol levels and retinol binding protein, they were found significantly increased in baboons with hepatic steatosis when compared to the control group, but they did not present any significant alteration in animals with fibrosis and cirrhosis. In rats, plasma retinol levels and RPB were significantly different between ethanol fed rats and control group. In both experiments the diets contained vitamin $\mathrm{A}$ as retynil acetate in usual amounts (5600Ul/day in 
baboons and 400Ul/day in rats). Researchers concluded that the vitamin A hepatic depletion induced by ethanol intake occurs in initial stages of liver disease. In baboons with hepatic steatosis, increased vitamin A plasma levels and retinol binding protein were not explained. The possible reasons found by the authors to explain the vitamin A hepatic depletion, in these two experimental groups, were the increase of mobilization of vitamin $A$ evidenced by the increase of concentration of vitamin A in the kidneys and the testis, and the increase of catabolism of vitamin A through the enzyme cytochrome P450 (CYP) induced by ethanol consumption.

The main CYP induced by ethanol is CYP2E1, which possesses a pronounced oxidative activity in metabolism of several compounds, resulting in increased production of acetaldehyde and free radical release ${ }^{48}$. CYP2E1 also has a high capacity to activate some commonly used drugs to their toxic metabolites and to promote carcinogenesis ${ }^{49}$. Liu et al. ${ }^{50}$ observed in vitro that the incubation of retinoic acid with microsomal fractions of hepatic tissue containing CYP2E1 from rats exposed to ethanol resulted in decrease of retinoic acid and the appearance of polar metabolites, which can be toxic to cellular membrane. Moreover, the treatment with chlormethiazole, an inhibitor of cytochrome system, in ethanol-fed rats restored the serum and hepatic concentrations of retinoic acid to normal levels. In another study, Liu et al. ${ }^{51}$, evaluating the effect of two different doses of chlormethiazole, in rats exposed or not to ethanol, observed that this inhibitor can restore the concentrations of retinol and hepatic retinyl esters in ethanol-fed rats by inhibiting the degradation of vitamin $A$ and the mobilization of vitamin $A$ from the liver to the bloodstream.

In order to evaluate the influence of ethanol on vitamin A supplementation and its hepatic effects, Leo et al. ${ }^{52}$ observed in an experimental study that in rats fed with a high dose of vitamin A (29000Ul/day for 8 weeks) there was a significant increase of hepatic vitamin A when compared to the group that received normal vitamin A diet (5800Ul/day for 8 weeks). A slighter increase was observed in the group that received the combination high vitamin A diet and ethanol (36\% of total colories) possibly because of an increased vitamin A catabolism in the liver after chronic ethanol consumption. These researchers observed that even the group that received ethanol and normal vitamin A diet presented mild mitochondrial alterations and proliferation of the smooth endoplasmic reticulum, just as the control group that received only high vitamin A diet. By contrast, the high vitamin A-ethanol group showed much more striking lesions with enlarged mitochondria, confirming the hepatotoxicity of this vitamin and potentiation of its effect by ethanol.

In another analysis, Leo \& Lieber ${ }^{53}$ observed an increased number of Ito cells after the administration of diet with high concentration of vitamin A (29000Ul/day for 2 or 9 months) in rats, but in the groups that received diet containing ethanol and high concentration of vitamin A was observed a decrease in the number of these cells, which matches with the decrease of hepatic vitamin A storage and the appearance of myofibroblasts and collagen fibers. This way, retinoids may play a role in the development of cirrhosis induced by ethanol.

These researchers also observed that retinol is not directly responsible for these hepatic alterations since after a chronic ethanol intake, hepatic levels of vitamin A were smaller than when compared to control group, yet signs of toxicity were more prominent. It can be explained by the induction of cytochrome P450 by ethanol, which promotes the hydrolysis of retinoic acid, a physiologically active derivate from retinol, in polar metabolites, which might participate in toxicity ${ }^{23,54-56}$. Thus, ethanol can potentiate the toxicity of retinol.

Recently, Dan et al. ${ }^{57}$ showed that polar retinol metabolites caused marked cytotoxicity in 
a concentration and time-dependent manner in HepG2 cells (human hepatoma cell line) and primary hepatocytes from rats fed with ethanol. These authors demonstrated that this toxicity was due to induction of apoptosis by polar retinol metabolites. These findings explain the mechanism by which ethanol potentiate vitamin A hepatotoxicity.

The reduction of serum levels of retinoic acid can, in part, be justified by the increase of its degradation as consequence of chronic ethanol consumption. The decrease of biosynthesis of retinoic acid can also be involved, since ethanol inhibits the oxidation of retinol by alcohol dehydrogenase ${ }^{58}$. Wang et al. ${ }^{59}$ suggested that decreased liver and plasma retinoic acid induced by chronic alcohol feeding (36\% of total calorie intake for 1 month) in rats could be caused by inhibition of retinol oxidation, increased catabolism of retinoids via ethanol-induced cytochrome P450 enzymes, lower amounts of retinol and retinyl palmitate, precursors of retinoic acid, in liver of ethanol-fed rats, which could result from reduced intestinal absorption or hepatic uptake, and increased mobilization of vitamin A from liver to other organs.

Molotkov \& Duester ${ }^{60}$ observed in retinoidtreated $(10 \mathrm{mg} / \mathrm{kg}$ of retinoic acid) mice exposed to acute ethanol intoxication $(3,5 \mathrm{~g} / \mathrm{kg})$ that the reduced levels of serum retinoic acid are due primarily to a decrease in retinoic acid synthesis, and secondarily to an increase in retinoic acid degradation, but both are significant.

Decreasing in hepatic retinoic acid may be a mechanism by which alcohol causes hepatocellular carcinoma, since retinoic acid is necessary for the cellular proliferation and differentiation 60,61 .

Only few studies have been carried out investigating the mechanisms leading to low circulating vitamin A levels in alcoholics or chronic liver disease patients, since methodological and ethical aspects limit studies in human beings. Besides, the utilization of hepatic biopsies in order to evaluate hepatic structural changes is limited in liver disease patients by a hepatic function impaired. In addition, animal models are useful in exploring basic science questions related to molecular biology, biochemical pathways and genetics that cannot be explored in human beings. Although these experimental studies have shown an adverse interaction between ethanol and retinol, they must be carefully interpreted. However, according to its results, in vitamin A deficiency the administration of pharmacological supplements needs cautions in relation to dose and adverse effects.

Based on these facts one should ask how supplement patients with alcoholic liver disease, mainly those who are still alcoholics, who demonstrate clinical signs of vitamin A deficiency. As previously shown, ethanol and vitamin A interactions may result in hepatotoxicity. Majumdar et al. ${ }^{46}$ supplemented 25 chronic alcoholic patients with 2500 Ul/day of vitamin A orally for 5 days. Three out of these patients were found to be vitamin A deficient (low serum levels) and after treatment was observed improvement of the blood levels in all, except two elderly males. However, these authors do not describe which type of liver injury these patients presented, although biochemical evidence of ethanol-induced liver damage were found in many of the patients. By this way, treated patients could be in different stages of liver disease and consequently may present different response to supplementation.

Since zinc is essential in vitamin $A$ metabolism, concomitant administration of zinc and vitamin A supplementation must be considered. Mobarhan et al. ${ }^{62}$, evaluated dark adaptation, zinc and retinol levels in a study carried out on 21 hospitalized male patients. Ten patients were found vitamin A deficient and with abnormal dark adaptation and two of these patients, were also zinc deficient. Those patients were treated with oral vitamin A supplementation (30000Ul/day for 4 weeks). Only three patients experienced a rise in serum retinol levels, suggesting that retinol levels may not be sensitive to monitor changing in vitamin A status than dark 
adaptation. After this period the two zinc-deficient patients remained with abnormal dark adaptation. These two patients were then additionally treated with 220mg of ZnSO4/day for 2 weeks, after which their dark-adapted thresholds returned to normal. By this way, vitamin A and zinc supplementation together may be more efficient than vitamin $A$ alone.

This review shows that ethanol can either potentiate vitamin A hepatotoxicity or its deficiency. So, other studies are necessary to investigate adequate dose and time of vitamin $\mathrm{A}$ supplementation in chronic alcoholism with or without liver disease, when and how to associate it with zinc supplementation.

\section{CONCLUSION}

Ethanol toxicity on liver is a function of duration of alcoholism, amount of daily intake of alcohol and patient's nutrition. Long-term alcohol intake results in reduced vitamin A ingestion and absorption, enhanced degradation in the liver, increased mobilization of retinol from the liver to other organs and in oxidative stress, increasing vitamin A demands. Moreover, chronic alcoholism results in impaired nutritional status of retinoic acid, the most active derivate of vitamin A, which may promote an environment for tumor formation, since retinoic acid is necessary for the cellular proliferation and differentiation. Indeed, reduced hepatic levels of vitamin A induced by ethanol may also result in hepatic structural alterations. So, in chronic alcoholic subjects, vitamin A serum levels and hepatic reserve need to be closely monitored to avoid deficiency and its adverse effects, although it is important to emphasize that vitamin A supplementation must be done carefully in vitamin A deficient patients, because dose commonly administrated in diseases of others etiology may be toxic for chronic ethanol consumer.

\section{REFERENCES}

1. Stewart SF, Day CP. The management of alcoholic liver disease. J Hepatol. 2003; 38(Suppl 1):S2-13.
2. Mendez Sanchez N. Alcoholic liver disease. An update. Ann Hepatol. 2005; 4(1):32-42.

3. Goodman DS. Vitamin A and retinoids in health and disease. N Engl J Med. 1984; 310(16): 1023-31.

4. Hendriks HF, Bosma A, Brouwer A. Fat-storing cells: hyper- and hypovitaminosis $A$ and the relationships with liver fibrosis. Semin Liver Dis. 1993; 13(1): 72-80.

5. Leo MA, Lieber CS. Hepatic vitamin A depletion in alcoholic liver injury. N Engl J Med. 1982; 307(10): 597-601.

6. Blomhoff R. Transport and metabolism of vitamin A. Nutr Rev. 1994; 52(2):Pt 2:S13-23.

7. Blomhoff R, Wake K. Perisunusoid stellate cells of the liver: important roles in retinol metabolism and fibrosis. Faseb J. 1991; 5(3):271-7.

8. Quadro L, Hamberger L, Colantuoni V, Gottesman ME, Blaner WS. Understanding the physiological role of retinol-binding protein in vitamin $A$ metabolism using transgenic and knockout mouse models. Mol Aspects Med. 2003; 24(6):421-30.

9. Ghyselinck NB, Bavik C, Sapin V, Mark M, Bonnier $D$, Hindelang $C$, et al. Cellular retinol-binding protein I is essential for vitamin A homeostasis. EMBO J. 1999; 18(18):4903-14.

10. Dawson HD, Yamamoto $Y$, Zolfaghari R, Rosales FJ, Dietz J, Shimada T, et al. Regulation of hepatic vitamin A storage in a rat model of controlled vitamin A status during aging. J Nutr. 2000; 130(5): 1280-6.

11.Sommer A. Vitamin A deficiency and its consequences: a field guide to detection and control - epidemiology. 3rd ed. Geneva: World Health Organization; 1995. 65p.

12. Blomhoff R, Green MH, Green JB, Berg T, Norum KR. Vitamin A metabolism: new perspectives on absorption, transport and storage. Physiol Rev. 1991; 171(4):951-90.

13. Janczewska I, Ericzon BG, Eriksson LS. Influence of orthotopic liver transplantation on serum vitamin A levels in patients with chronic liver disease. Scand J Gastroenterol. 1995; 30(1):68-71.

14. Institute of Medicine, Food and Nutrition Board. Dietary reference intakes for vitamin A, vitamin K, arsenic, boron, chromium, copper, iodine, iron, vanadium, manganese, molybdenum, nickel, silicon, vanadium and zinc. Washington (DC): National Academy Press; 2002.

15. Shiota G, Umeki K, Okano J, Kawasaki H. Hepatocyte growth factor and acute phase proteins in patients with chronic liver diseases. J Med. 1995; 26(5-6):295-308. 
16. Stephensen CB, Gildengorin G. Serum retinol, the acute phase response, and the apparent misclassification of vitamin A status in the Third National Health and Nutrition Examination Survey. Am J Clin Nutr. 2000; 72(5):1170-8.

17. Rocchi E, Borghi A, Paolillo F, Pradelli $M$, Casalgrandi G. Carotenoids and liposoluble vitamins in liver cirrhosis. J Lab Clin Med. 1991; 118(2):176-85.

18. Pugh RN, Murray-Lyon IM, Dawson JL, Pietroni MC, Willians R. Transection of the oesophagus for bleeding oesophageal varices. Br J Surg. 1973; 60(8):646-9.

19. Sklan D, Yosefov T, Friedman A. The effects of vitamin A, beta-carotene and canthaxanthin on vitamin A metabolism and immune responses in the chick. Int J Vit Nutr Res. 1989; 59(3):245-50.

20. Albillos A, Hera A. Multifactorial gut barrier failure in cirrhosis and bacterial translocation: working out the role of probiotics and antioxidants. J Hepatol. 2002; 37(4):523-6.

21. Roenigk $\mathrm{HH}$. Liver toxicity of retinoid therapy. Pharmacol Therap. 1989; 40(1):145-55.

22. Davis BH, Kramer RT, Davidson NO. Retinoic acid modulates rat Ito cell proliferation, collagen, and transforming growth factor beta production. J Clin Invest. 1990; 86(6):2062-70.

23. Leo MA, Sato M, Lieber CS. Effect of hepatic vitamin A depletion on the liver in humans and rats. Gastroenterology. 1983; 84(3):562-72.

24. Denk H, Franke WW, Kerjaschki D, Eckerstorfer R. Mallory bodies in experimental animals and man. Int Rev Exp Pathol. 1979; 20:77-121.

25. Franke WW, Schmid E, Kartenbeck, Mayer D, Hacker $H$, Bannash $P$, et al. Characterization of the intermediate-sized filaments in liver cells by immunofluorescence and electron microscopy. Biol Cellulaire. 1979; 34:99-110.

26. Borenfreund E, Schmid E, Bendich A, Franke WW. Constitutive aggregates of intermediate-sized filaments of the vimentin and cytokeratin type in cultured hepatoma cells and their dispersal by butyrate. Exp Cell Res. 1980; 127(1):215-35.

27. Leo MA, Lieber CS. Alcohol, vitamin A and beta carotene: adverse interactions, including hepatotoxicity and carcinogenicity. Am J Clin Nutr. 1999; 69(6):1071-85.

28. Reeves HL, Burt AD, Wood S, Day CP. Hepatic stellate cell activation in the absence of hepatitis in alcoholic liver disease and correlates with the severity of steatosis. J Hepatol. 1996; 25(5): 677-83.

29. Svegliati-Baroni G, Ridolfi F, Sario A, Saccomanno $S$, Bendia $E$, Benedetti $A$, et al. Intracellular signaling pathways involved in acethaldeyde induced collagen and gene expression in human hepatic stellate cells. Hepatology. 2001; 33(5):1130-40.

30. Savolainen ER, Leo MA, Timpl R, Lieber CS. Acetaldehyde and lactate stimulate collagen synthesis of cultured baboon liver myofibroblasts. Gastroenterology. 1984; 87(4):777-87.

31. Moshage H, Casini A, Lieber CS. Acetaldehyde selectively stimulates collagen production in cultured rat liver-storing cells but not in hepatocytes. Hepatology. 1990; 12(3)Pt 1:511-8.

32. Tanaka Y, Funaki N, Mak IM, Kim C, Lieber CS. Effects of ethanol and hepatic vitamin $A$ on proliferation of lipocytes in regenerating rat liver. J Hepatol. 1991; 12(3) 344-50.

33. Davis $B H$, Vucic $A$. The effect of retinol on Ito cell proliferation in vitro. Hepatology. 1988; 8(4):78893

34. Friedman SL, Wei S, Blaner WS. Retinol release by activated rat hepatic lipocytes: regulation by Kupffer cell- conditioned medium and PDGF. Am J Physiol. 1993; 264(5)Pt 1:G947-52.

35. Seitz HK. Alcohol and retinoid metabolism. Gut. 2000; 47(6):748-50.

36. Stickel F, Hoehn B, Schuppan D, Seitz HK. Nutritional therapy in alcoholic liver disease. Alim Pharmacol Therap. 2003; 18(4):357-73.

37. Calamita A, Dichi I, Papini-Berto SJ, Dichi JB, Angeleli AV, Vannucchi $\mathrm{H}$. Plasma levels of transthyretin and retinol-binding protein in ChildA cirrhotic patients in relation to protein-calorie status and plasma amino acids, zinc, vitamin A and plasma thyroid hormones. Arq Gastroenterol. 1997; 34(3):139-47.

38. Masalkar PD, Abhang SA. Oxidative stress and antioxidant status in patients with alcoholic liver disease. Clin Chim Acta. 2005; 355(1-2):61-5.

39. Mobarhan S, Seitz HK, Russel RM, Mehta R, Hupert J, Friedman $\mathrm{H}$, et al. Age-related effects of chronic ethanol intake on vitamin A status in Fisher 344 rats. J Nutr. 1991; 121(4):510-7.

40. Sato M, Lieber CS. Changes in vitamin A status after acute ethanol administration in the rat. J Nutr. 1982; 112(6):1188-96.

41. Ukleja A, Scolapio JS, McConnel JP, Spivey JR, Dickson RC, Ngayen JH, et al. Nutritional assessment of serum and hepatic vitamin A levels in patients with cirrhosis. JPEN J Parenter Enteral Nutr. 2002; 26(3):184-8.

42. McCullough AJ, Bugianesi E. Protein-calorie malnutrition and the etiology of cirrhosis. Am J Gastroenterol. 1997; 92(5):734-8. 
43. Zaína FE, Parolin MB, Lopes RW, Coelho JCU. Prevalence of Malnutrition in Liver Transplant Candidates. Transplant Proc. 2004; 36(4):923-5.

44. Maio R, Dichi JB, Burini RC. Nutritional consequences of metabolic impairment of macronutrients in chronic liver disease. Arq Gastroenterol. 2000; 37(1):52-7.

45. Bell H, Nilsson A, Norum KR, Pedersen LB, Racknerud N, Rasmussen $M$. Retinol and retinyl esters in patients with alcoholic liver disease. J Hepatol. 1989; 8(1):26-31.

46. Majumdar SK, Shaw GK, Thomson AD. Vitamin A utilization status in chronic alcoholic patients. Int J Vitam Nutr Res. 1983; 53(3):273-9.

47. Sato M, Lieber CS. Hepatic vitamin A depletion after chronic ethanol consumption in baboons and rats. J Nutr. 1981; 111(11):2015-23.

48. Lieber CS. Cytochrome P-4502E1: its physiological and pathological role. Physiol Rev. 1997; 77(2): 517-44.

49. Lieber CS. Microsomal ethanol oxidizing system (MEOS): the first 30 years (1968-1998): a review. Alcohol Clin Exp Res. 1999; 23(6):991-1007.

50. Liu C, Russel RM, Seitz HK, Wang XD. Ethanol enhances retinoic acid metabolism into polar metabolites in rat liver via induction of cytochrome P4502E1. Gastroenterology. 2001; 120(1):179-89.

51. Liu C, Chung J, Seitz HK, Russel RM, Wang XD. Chlormethiazole treatment prevents reduced hepatic vitamin A levels in ethanol-fed rats. Alcohol Clin Exp Res. 2002; 26(1):1073-9.

52. Leo MA, Arai M, Sato M, Lieber CS. Hepatotoxicity of vitamin $A$ and ethanol in the rat. Gastroenterology. 1982b; 82(2):194-205.

53. Leo MA, Lieber CS. Hepatic fibrosis after long- term administration of ethanol and moderate vitamin A supplementation in the rat. Hepatology. 1983; 3(1):1-11.

54. Adachi S, Moriwaki H, Muto $Y$, Yamada $Y$ Fukutomi $Y$, Shimazaki $M$, et al. Reduced retinoid content in hepatocellular carcinoma with special reference to alcohol consumption. Hepatology. 1991; 14(5):776-80.

55. Russel RM. The vitamin A spectrum: from deficiency to toxicity. Am J Clin Nutr. 2000; 71(4):878-84.

56. Russel RM. The impact of disease states as a modifying factor for nutrition toxicity. Nutr Rev. 1997; 55(2):50-3.

57. Dan Z, Popov Y, Patsenker E, Preimel D, Liu C, Wang $X D$, et al. Hepatotoxicity of alcohol-induced polar retinol metabolites involves apoptosis via loss of mitochondrial membrane potential. FASEB J. 2005; 19(7):845-7.

58. Deltour L, Ang HL, Duester G. Ethanol inhibition of retinoic acid synthesis as a potential mechanism for fetal alcohol syndrome. FASEB J. 1996; 10(9): 1050-7.

59. Wang XD, Liu C, Chung J, Stickel F, Seitz HK, Russel RM. Chronic alcohol intake reduces retinoic acid concentration and enhances AP1 (c-Jun and c-Fos) expression in rat liver. Hepatology. 1998; 28(3): 744-50.

60. Molotkov A, Duester G. Retinol/ethanol drug interaction during acute alcohol intoxication in mice involves inhibition of retinol metabolism to retinoic acid by alcohol dehydrogenase. J Biol Chem. 2002; 277(25):22553-7.

61. Morgan TR, Mandayam S, Jamal MM. Alcohol and hepatocellular carcinoma. Gastroenterology. 2004; 127( 5 Suppl 1):S87-96.

62. Mobarhan S, Russel RM, Underwood BA, Wallingford J, Mathieson RD, Al Midani $H$. Evaluation of the relative dose response test for vitamin A nutriture in cirrhotics. Am J Clin Nutr. 1981; 34(10):2264-70.

Submitted on: 28/2/2005

Final version resubmitted on: $21 / 3 / 2006$ Approved on: 15/8/2006 